DOI: 10.31933 /DIJEMSS

Received: $25^{\text {th }}$ August 2020, Revised: $25^{\text {th }}$ September 2020, Publish: $18^{\text {st }}$ November 2020

$\begin{array}{|ll|} & \text { DIJEMSS } \\ & \text { DINASTI INTERNATIONAL JOURNAL } \\ & \text { OF EDUCATION MANAGEMENT AND }\end{array}$

\title{
THE EFFECT OF JOB SATISFACTION, PROCEDURAL FAIRNESS AND WORK MOTIVATION ON TEACHER PERFORMANCE IN SMA YUPPENTEK 1 TANGERANG MUNICIPALITY
}

\author{
Moh Abror ${ }^{1}$ \\ 1) Magister of Management, Mercu Buana University, Indonesia, mohabror41554@gmail.com
}

\begin{abstract}
This study aims to prove the influence of job satisfaction, procedural fairness and work motivation on teacher performance at Yuppentek 1 High School in Tangerang Municipality. By using $100 \%$ of a sample of 71 teachers, the main instrument was in the form of a questionnaire. Data in this study were analysed using (1) descriptive analysis of respondent characteristics (2) descriptive analysis of research variables and (3) analysis of Partial Least Square (PLS)-Structural Equation Modelling (SEM) with smartly 3.0. The results indicated that based on the results of data testing, the evaluation of the measurement model was valid and reliable and could be received substantially. Partial Least Square application test results showed that $73.3 \%$ of teacher performance variance is influenced by teacher job satisfaction. While $56.9 \%$ of the variance in teacher performance is influenced by procedural fairness in schools and $53.1 \%$ of the variance in teacher performance is influenced by teacher work motivation. Interpretation of the results of $R$ Square and $R$ Square Adjusted resulted that $48.6 \%$ of teacher performance is influenced by job satisfaction, procedural justices and teacher work motivation. However, 51.4\% of teacher performance variance is influenced by other factors out of job satisfaction, procedural justice and teacher work motivation
\end{abstract}

Keywords: teacher performance, job satisfaction, procedural fairness, motivation, Structural Equation Modelling (SEM), Partial Least Square (PLS).

\section{INTRODUCTION}

Schools are formal educational institutions in which their development have made many innovations to meet human resource needs. One of the human resources in schools that determines the success and existence of a school is teachers. Teachers are educators who hold professional positions. As stated in the Law of the Republic of Indonesia number 20 of 2003 article 35, teachers are required to continue to develop themselves in accordance with the times, science and technology, as well as the needs of society. In the other words, teachers are always required to improve their quality and to a certain extent teacher quality is assessed by their performance. 
The pre-survey conducted at SMA Yuppentek I Kota Tangerang previously revealed that some aspects related to management are of low value. The aspects are among others; job satisfaction, procedural justice, and performance of teachers. The results of the pre-survey recapitulation showed that there was a low percentage score on job satisfaction, which is only $25.7 \%$, procedural fairness at the point of $34.3 \%$, motivation $(42.8 \%$ ), and performance $(51.4 \%)$. Therefore, job satisfaction, procedural fairness and motivation and performance need to be addressed in more comprehensive way.

To be more specific, teacher performance had not been satisfyingly achieved yet. Seen from Teacher Self-Evaluation result, performance related to the preparation of programs, learning syllabus and targets still need to be improved. Meanwhile, teachers has not met their job satisfaction yet, especially on the aspect of compensation and the sense of fairness in the workplace. Also, teachers admitted that they lacked motivation in doing self development. These three main points were suspected to be the reason why teacher performance is satisfying or dissatisfying.

The result of the pre-survey above led the researcher to conduct a research entitled "The Effect of Job Satisfaction, Procedural Justice and Work Motivation on Teacher Performance in SMA Yuppentek 1Tangerang Municipality" The study aimed to find out and explain (1) the effect of job satisfaction on teacher performance at SMA Yuppentek 1 Kota Tangerang, (2) the effect of procedural justice on teacher performance at SMA Yuppentek 1 Kota Tangerang, (3) the effect of work motivation on teacher performance at SMA Yuppentek 1 Kota Tangerang and (4) the simultaneous effect of job satisfaction, procedural justice, and work motivation on the work performance of SMA Yuppentek 1 teachers in Tangerang Municipality.

\section{LITERATURE REVIEW}

Based on the variables of the research, the followings are discussed in detail to get more comprehensive summary of the research topic from previous research, books and experts.

\section{Job Satisfaction}

Luthans (2011) defines job satisfaction as "a happy emotional state or positive emotion that comes from a job appraisal or someone's work experience". Meanwhile, Hasibuan (2012) argues that job satisfaction is "a pleasant or unpleasant state in which employees view their work". According to Sinambela (2016) job satisfaction can provide positive energy to organizational activities, employees who have a high level of job satisfaction tend to produce high performance in carrying out job.

The job satisfaction variables in this research refer to the opinion of Robbins and Judge (2013:79), namely; (1) the work itself with indicators: assignments, learning opportunities, and responsibilities, (2) current salary, with indicators: payroll system and fairness of payroll, (3) promotion opportunities, with indicators: promotion opportunities, (4) leadership, with indicators: leadership style and (5) colleagues, with indicators: support between colleagues

\section{Procedural Fairness}

Hajiyanti (2013) states that procedural fairness is a perception aimed at employees when they see the company is implementing existing rules fairly. In addition, Raymond (2011) mentions that there are six important principles that determine whether people feel the procedures they receive are fair enough. These principles include consistency, elimination of bias, accuracy of information, possibility of correction, representativeness, and unity. In other words, procedural 
fairness is how employees understand the impartiality of the policy makers in an organization or institution where they serve. Procedural fairness relates to their perception of a form of fairness from all processes that have been implemented by superiors in the company, and when it is used to evaluate the performance of their employees.

Referring to (Irawan \& Sudarma, 2016), there are two dimensions for procedural fairness; fair formal procedure and interaction-al fairness (justice). To be precise, fair formal procedures is rules made by employees to be obeyed and executed properly. Fair procedure means rules made should involve all employees. It can be said that employees participate in decision making of rules or procedures. Meanwhile, Interaction-al fairness refers to the extent to which an authority given to employees to communicate properly. It displays a condition of activity that does not intersect with work, but rather on the aspects of interaction both informally and interpersonally.

\section{Motivation}

According to Sunyoto (2013) work motivation is a condition that encourages an individual to carry out certain activities to achieve his or her desires. Motivation in a person is a force that manifests in a behaviour to achieve his or her own satisfaction or goals in specific types of activities. In addition, Sutrisno (2012) is a factor that encourages someone to do a certain activity, therefore it is interpreted as a driving factor for someone's behaviour. Motivation is also defined as a process that describes a person's strength, direction, and persistence in an effort to achieve goals (Robbins and Judge, 2015).

It can be concluded that motivation is the reason which becomes the basis for a person's enthusiasm to do something in order to achieve the goals he has targeted. It is considered crucial because motivation can determine whether the target or goal of a person at work is worth continuing. At workplace, motivation is a skill in directing or controlling and moving someone to take action on the desired behaviour based on the goals that have been set.

Referring to Wibowo (2011), the dimensions and indicators of motivation are as follows: (1) need for achievement, indicators include; work targets, quality of work, responsibilities and risks, (2) the need to expand relationships, indicators include; communication and friendship and (3) the need to master a job, as indicators are; leaders, company ambassadors and role models.

\section{Teacher Performance}

Wahyudi (2012) explains that performance is the result of work that can be achieved by a person or group of people in an institution, in accordance with their respective authorities and responsibilities. Moreover, according to Sadiyo (2014), performance is the result of work that can be achieved by a person or group of people in an organization legally, which does not violate the law and is in accordance with morals and ethics.

Within the scope of schools as institutions, there are factors that affect performance, namely: motivation to work, responsibility for tasks, guidance in completing tasks, opportunities for development, attention from school principals, teacher interpersonal relationships, teacher association and teacher groups work (Rahmawati and Tarsis, 2014). To conclude, job satisfaction and the development of human resources are significant factors that affect teacher performance in institutions such as school.

In particular, Supardi (2014) suggests dimensions and indicators related to teacher performance variables, namely; quality of work, teacher speed/accuracy, work initiative, work ability, and communication. The indicators of work quality are mastering learning materials, managing the teaching and learning process, and managing the class. Work speed /accuracy has 
some indicators, namely; use of media or learning resources, mastery of the foundation of education, and the planning of learning programs. While initiatives at work has indicators; leading classes, managing teaching and learning interactions, assessing student learning outcomes. Finally, workability includes indicators; the use of various methods in learning, understanding and implementing extension guidance functions and services.

\section{Theoretical Framework}

Previous research conducted by Reza Ahmadiansah (2016) revealed that work motivation has a positive and significant effect on teacher performance. In addition, job satisfaction positively and significantly affect performance of SMK Muhammadiyah Salatiga teachers. Other research conducted by Linda Sulistiyani in 2015 found that job satisfaction and work motivation have positive effects on teacher performance. $51.7 \%$ of teacher performance is influenced by job satisfaction and work motivation, the remaining $48.3 \%$ is influenced by other variables outside the study. In addition, Ashraf, Veinhardt, Raheem Ahmed, Streimikiene and Ahmed Mangi, in 2018 published their research which showed that procedural justice has influence on wok performance of employees and interaction-al justice fully intervened the relationship between procedural justice and three types of job performance of employees in South Asian countries.

The research results above led to the framework of this research. The inter connection of research variables is described in the following figure.

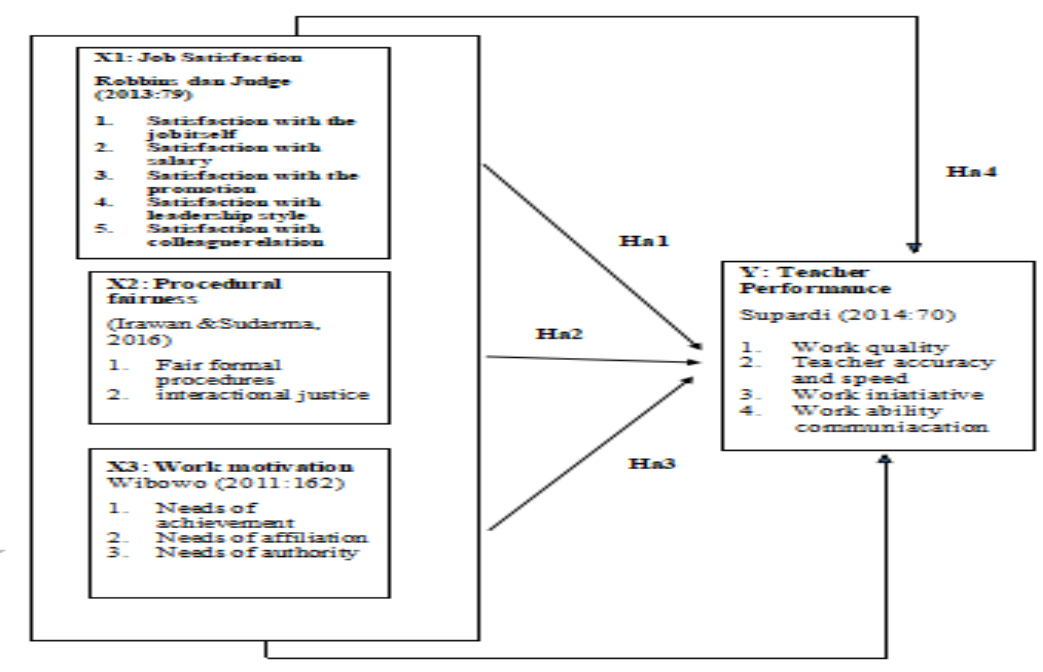

Figure 1: conceptual framework

Source: research processed by writer (2019)

\section{Hypothesis}

The study proposed some hypothesis which are based on the formulation of the problem and the theoretical framework to answer the research objectives. They are:

Ha1: Job satisfaction positively and significantly affects teacher performance.

Ha2: Procedural justice positively and significantly affects teacher performance.

Ha3: Work motivation positively and significantly affects teacher performance.

Ha4: Job satisfaction, procedural fairness and work motivation simultaneously have significant effects on teacher performance.. 


\section{RESEARCH METHODS}

\section{Research Variables}

The purpose of this study was to explain the position of the variables and the relationship between one variable and other variables and therefore it is called associative or relationship research. According to Sugiyono (2003: 11) associative research is research aiming to determine the effect or relationship between two or more variables.

There are two variable in this study, namely exogenous and endogenous variables. According to Santoso (2014: 9), exogenous variables are independent variables that affect the dependent variable. In the SEM model, exogenous variables are indicated by the presence of arrows that originate from these variables towards endogenous variables and are not influenced by other variables. The exogenous variables in this study are Job Satisfaction as X1, Operational Justice as X2, and Work Motivation as X3. Moreover, Santoso (2014: 9) explains that endogenous variable sare dependent variables that are influenced by independent (exogenous) variables. In the SEM model, exogenous variables are indicated by the presence of arrows leading to these variables (Santoso, 2014: 9). So that endogenous variables are influencing and influenced by other variables. In this study, the endogenous variable (Y) is teacher performance.

\section{Population and Sample}

This study employed sample taking technique called saturated samples or census samples. According to Arikunto (2010: 104), if the population is less than 100 people, the whole sample is taken. Therefore, the study used $100 \%$ of the total population at SMA Yuppentek 1 Kota Tangerang. The total number of 71 teachers became the sample of this study.

\section{Method of Analysis}

In this study, data were analysed by using descriptive analysis and PLS (Partial Least Square) analysis. Data related to the characteristics of respondents were analysed descriptively to provide an overview of the characteristics of the respondents. In this study, gender, age, level of education were descriptively analysed by presenting pie chart to show the percentage.

Moreover, descriptive analysis of research variables were also conducted by using the level categorization method (Azwar, 2012), aimed to place individuals in separate groups tiered according to a continuum based on the attributes measured. Specifically, the score of respondents' answers on each question item is categorized into 3 categories, namely low, medium and high category. The categorization of these answers is based on the categorization of scores suggested by Azwar (2012), by looking into the mean (M) and standard deviation (SD) values.

Table 1. Scoring Categorization

\begin{tabular}{ll}
\hline \multicolumn{1}{c}{ Criteria } & \multicolumn{1}{c}{ Interval } \\
\hline Low & $\mathrm{X}<\mathrm{M}-\mathrm{SD}$ \\
\hline Medium & $\mathrm{M}-\mathrm{SD}<\mathrm{X}<\mathrm{X}<\mathrm{M}+\mathrm{SD}$ \\
\hline High & $\mathrm{M}+\mathrm{SD}<\mathrm{X}$ \\
\hline
\end{tabular}

Note:

$\mathrm{M}:$ Mean

SD: Standard Deviation

$X$ : Score

As for the PLS (Partial Least Square) analysis, based on the operational definition of each research variable, the PLS model specifications to be estimated in this study are as follows: 


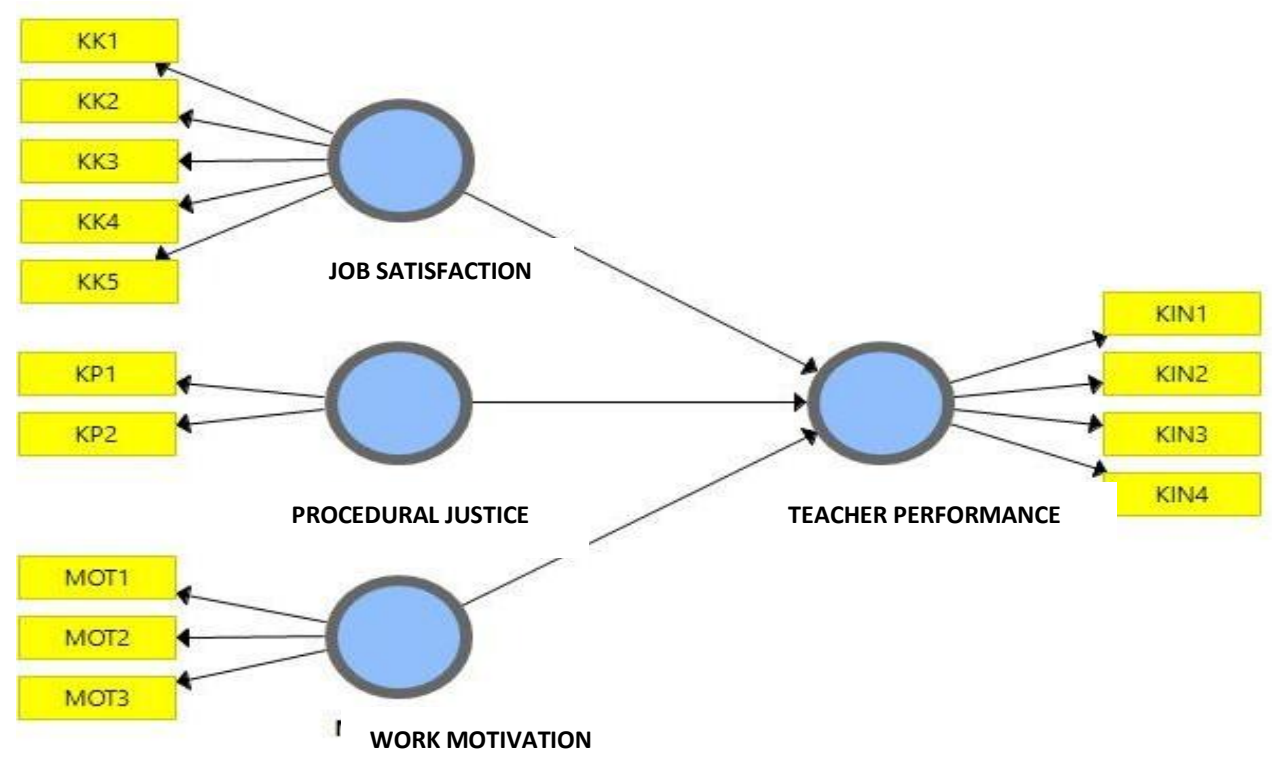

Figure 2. PLS Model Specification

The stages in the PLS analysis include first, measuring the outer model of first order construct, then measuring the goodness of fit model and finally measuring the inner model.

Outer measurement model includes measurements of Convergent Validity Discriminant Validity and Composite Reliability to meet the validity and the reliability of the construct.

After fulfilling the validity and reliability of the construct at the testing stage of the outer model, the test is continued to test the Goodness of fit model. The fit of the PLS model can be seen from the SMRM (Standardized Root Mean Residual) value of the model. The PLS model is declared to have met the goodness of fit model criteria if the SRMR value is $<0.10$ and the model is declared perfect fit if the SRMR value is $<0.08$.

Inner masurement model is also called inner relation, structural model and substantive theory, which describes the relationship between latent variables, based on the substantive theory. Inner model analysis is evaluated using R-square for the dependent construct, StoneGeisser Q-square test for predictive relevance and t test together with the significance of the structural path parameter coefficients.

For hypothesis testing, it is resulted from the t-statistic value and probability value. The statistical value for alpha is $5 \%$ and the t-statistic value used is 1.96 . Then the criterion of Ha (exogenous variables affect endogenous variables) and Ho (exogenous variables do not affect endogenous variables) for acceptance or rejection is decided when the t-statistic $>1.96$. To reject or accept the hypothesis, probability is applied. Ha (exogenous variables affect endogenous variables) is accepted if the $\mathrm{p}$ value is $<0.05$.

\section{FINDINGS AND DISCUSSION}

This research was conducted at SMA Yuppentek 1 Tangerang Municipality. YUPPENTEK is an extension of the Technology Education Improvement Business Foundation established on January 16, 1968. SMA Yuppentek 1 was founded on August 18, 1983. This school was built on an area of 5,590 M2 and located on Jalan Perintis Kemerdekaan I number 1 Tangerang. It is legally based on the Minister of Home Affairs Decree dated February 26, 1986 number: SK .17 / HP / DA / 86. As non governement school, SMA Yuppentek I maintains the continuity of this business sector by developing many innovations, improving the quality of teachers and working with students' parents to accommodate goals of the clients and also collaborating with the best universities in Jakarta, such as Mercu Buana University for alumni to continue their education. 
Descriptive analysis of respondents was conducted to provide an overview of the characteristics of the respondents based on gender, age and education. The number of respondents in this study were 71 respondents. The following pictures of 1,2 and 3 are the results of a descriptive analysis.

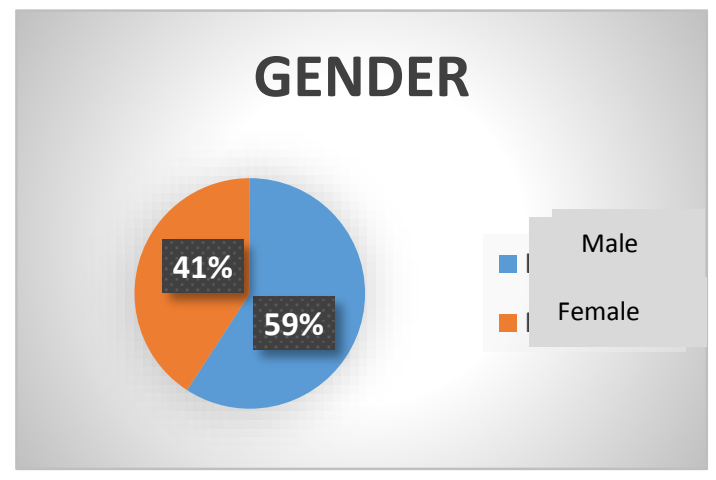

Picture 1. Gender of Respondents

The results of the analysis show that of the 71 respondents examined in this study, most of the respondents were male, 42 of them (59.2\%), while the remaining, 29 of them (40.8\%) were female.

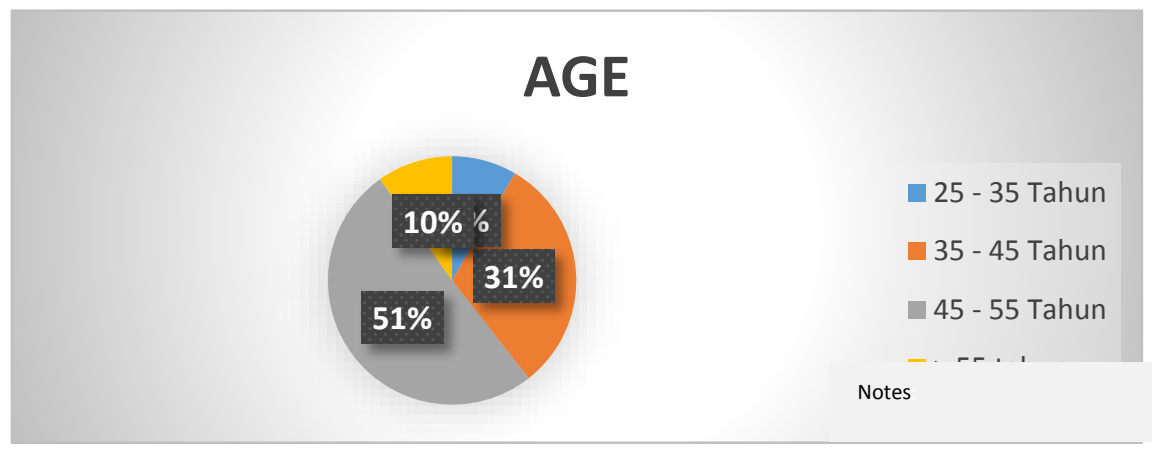

Picture 2. Age of Respondents

Based on the results of the analysis, of the 71 teachers involved in this study, most of the teachers (36 of them) were aged $45-55$ years $(50.7 \%$ ), while the rest were ( 6 teachers) or $8.5 \%$ teachers aged 25-35 years, 22 teachers or $31 \%$ aged 3545 years and 7 teachers or $9.9 \%$ of respondents aged above 55 years.

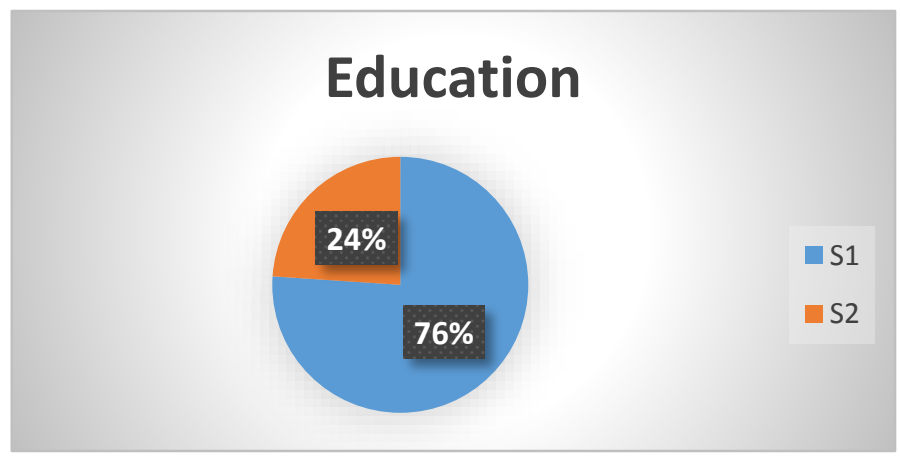

Picture 3. Educational Background of Respondents

The results of the analysis show that of the 71 respondents, 54 of them were teachers with an undergraduate education $(76.1 \%)$, while the remaining $23.9 \%$ (17 teachers) were holding master degree. 
The next finding is about the descriptive analysis of the research variables, namely; job satisfaction, procedural fairness, motivation and teacher performance.

The first variable is job satisfaction. In average, the teachers' job satisfaction variable was in the high category, especially on the item that teacher's work had matched the interests of most teachers. They also believed that their work was interesting and decisions taken by superiors do not disadvantage them and other co-workers. However, there were some lowest score that made the job less satisfied to the respondents. The respondents scores in the certain items are low. For instance, they felt less satisfied with the progress of their students, they thought that institutions have not fully

provided more possible opportunity for those who have the potential for certain positions. They also felt dissatisfied with the superiors' attitudes in giving directions and the guidance needed. Moreover, tThe way superiors interact personally with teachers and teacher co-workers, the attitudes of superiors in understanding the needs of teachers and colleagues and team work needed to address more seriously because respondents scored those items low.

The descriptive analysis of the second variable which is about procedural fairness showed that the average value of each indicator in the procedural justice variable was in the high category. It is interpreted that basically most of the teachers who work at SMA Yuppentek 1 Tangerang agreed that procedural is good. However, several aspects of procedural fairness in this school still need to be improved, namely; (1) the rules and decisions of their institutions were not made by deliberation by consensus in terms of decision making yet, (2) not all teachers were involved in the decision making, Some still believed that decisions and rules were not fair and equitable, and (4) some agreed that superiors sometimes could not control emotions and speak politely in public.

The next variable that is analysed descriptively is respondents'motivation. Work motivation is measured by 16 indicators in the form of statements displayed in questionnaire. The results of the analysis show that in general most of the teachers at SMA Yuppentek 1 Tangerang already have high work motivation. The biggest contributors were that because (1) institutions give rewards when work targets are achieved, (2) comfortable and healthy interactions at work due to the fulfillment of work responsibilities implemented seriously and because of (3) the closeness and brotherhood in the work community gave respondents motivation to work well. However, there were several things that could reduce the work motivation of teachers in this school. The analysis showed that the causes are; (1) the teacher is not challenged by the work target given, (2) the institution does not reward and punish when they deserved it, (3) They do not have many opportunities to become leaders even though they are considered to be outstanding and (4) teachers felt less enthusiastic to work better to be leaders.

The result of descriptive analysis of the last variable, teacher performance, showed that the average score of each indicator was in the high category. It can be assumed that basically most of the teachers at SMA Yuppentek 1 Tangerang had performed well at work. The good performance can be seen, especially in terms of the ability of teachers, apart from teaching, they were also willing to guide students in terms of attitudes, skills and knowledge. In addition, most teachers were also happy to help the community to get to know their institution better. Most of the teachers also did an assessment of learning outcomes at the end of each lesson and most of them had good skills in leading the class. There are some points which need to improve for the scores are still low, namely (1) teachers needed to use different learning media according to class characters and teaching materials, (2) teachers needed to teach with various learning resources to accommodate classes with different student characters, (3) teachers shouldnot feel doubt to implement the mandate of the education law in the classroom, (4) teachers should ensure that their students interact so that learning occurs and (5) teachers should practice various kinds of learning methods. 
The next findings and discussion focus on the result of PLS (Partial Least Square) analysis. Beginning with Outer Model Measurement, it is found out that the all indicators have a loading factor value above 0.7 so that the model meets the convergent validity requirements. The following picture is the result of estimation of PLS model.

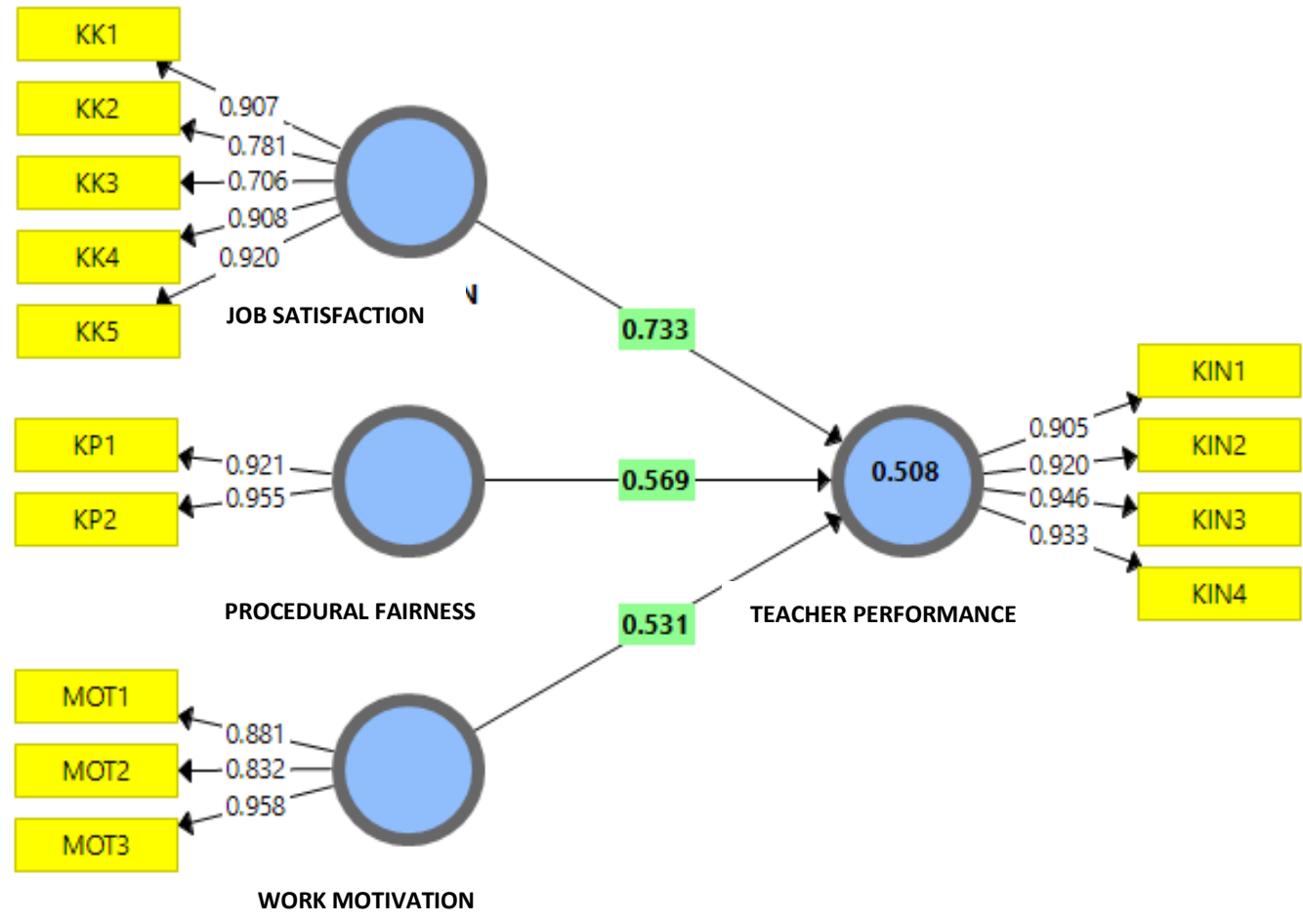

Figure 3. Estimation of PLS Model

Other than looking at the loading factor value of each indicator, convergent validity is also assessed from the AVE value of each construct, the PLS model is declared to have met the convergent validity if the AVE value of each construct is $>0.5$. The AVE value of all constructs, both in the form of dimensions and variables, has exceeded 0.5 which indicates that all indicators in each construct have met the convergent validity criteria required.

The next testing is discriminant validity, which is used to ensure that each concept of a latent variable is different from other variables. The result is as follow:

Tabel 2. Result of discriminant validity

\begin{tabular}{ccccc}
\hline & KIN & KK & KP & MOT \\
\hline KIN & 0.926 & & & \\
\hline KK & 0.614 & 0.849 & & \\
\hline KP & -0.415 & -0.789 & 0.938 & \\
\hline MOT & 0.553 & 0.622 & -0.763 & 0.892 \\
\hline
\end{tabular}

The results of the discriminant validity test in the table above indicate that all constructs have an AVE's square root value above the correlation value, with other latent constructs. It is concluded that the model has met the discriminant validity.

The reliability of the constructs is also assessed from the Crombachs Alpha value and the Composite Reliability value of each construct. The recommended composite reliability and Cronbachs alpha value is more than 0.7. However in development research, because the loading factor limit used is low (0.5), the composite reliability and Cronbachs alpha values are low still acceptable as long as the requirements for convergen and discriminant validity has been fulfilled. The following table shows the result. 
Table 3. Result of Composite Realibilty

\begin{tabular}{ccc}
\hline Variabel & Cronbach's Alpha & Composite Reliability \\
\hline KIN & 0.945 & 0.949 \\
\hline KK & 0.903 & 0.947 \\
\hline KP & 0.866 & 0.915 \\
\hline MOT & 0.870 & 0.877
\end{tabular}

The reliability test results in the table above show that all constructs have a composite reliability value> 0.7 and Cronbachs alpha> 0.7 which indicates that all constructs have met the required reliability.

After fulfilling the validity and reliability of the construct at the testing stage of the outer model, the test continues to the measurement of Goodness of Fit model. The fit of the PLS model can be seen from the SMRM model value. The PLS model is declared to have met the goodness of fit model criter: JOB SATISFACTION ralue is $<0.10$ and the model is declared perfect fit if the SRMR value is <0.08. The JOB SATISFAction ws:

Table 4. Goodness of Fit Model

\begin{tabular}{ccc}
\hline Kriteria GOF & Saturated Model & Estimated Model \\
\hline SRMR & 0.074 & 0.074 \\
\hline
\end{tabular}

The results of the PLS goodness of fit model testing showed that the SRMR value of the model in the saturated model is 0.074 and the estimated model is 0.074 . As the SRMR value of both the saturated model and the estimated model is below 0.10 , the model is declared perfect fit and feasible to use to test the research hypothesis.

The next step of PLS analysis is measuring the inner model that includes the direct effect test, the indirect effect test and the test of the influence of each exogenous variable to the endogenous variable. All of these tests are used to test the research hypothesis. The results of the model estimation which employed as a reference for testing the hypothesis in this study can be seen in the following figure.

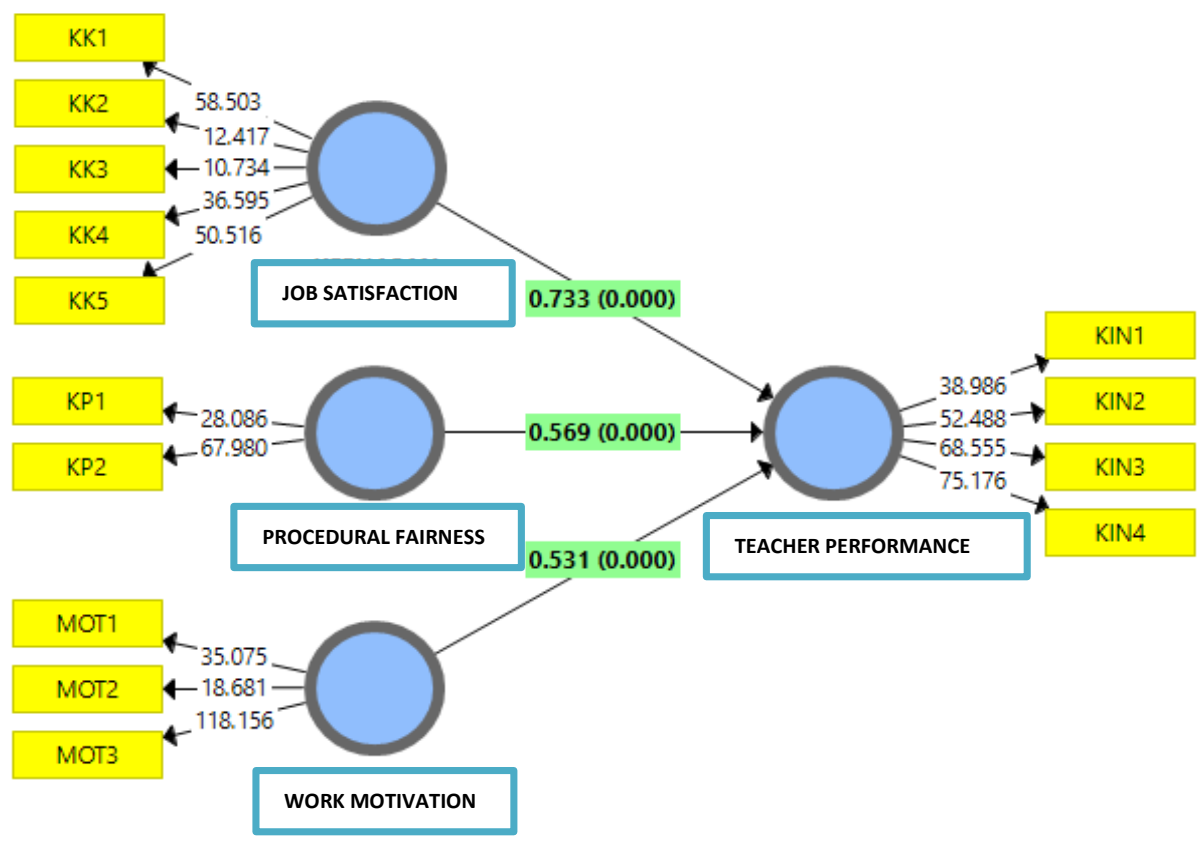

Figure 4. Estimation of PLS Bootstrapping Model 
Based on the results of hypothesis testing above, the following test results are obtained. First, the $\mathrm{p}$ value for the effect of job satisfaction on teacher performance (KK KIN) is 0.000 with a $\mathrm{T}$ statistic of 7.944 and the path coefficient is positive at 0.733 . As the $\mathrm{p}$ value $<0.05, \mathrm{~T}$ statistic> 1.65 and path coefficient is positive, it can be concluded that job satisfaction has a positive and significant effect on teacher performance. Based on the path coefficient value that connects the two variables, it can be concluded that $73.3 \%$ of the variance in teacher performance is influenced by teacher job satisfaction.

The $\mathrm{p}$ value of the effect on procedural fairness on teacher performance (KP KIN) is 0.000 with a $\mathrm{T}$ statistic of 3.959 and the path coefficient is positive at 0.569 . Because the $\mathrm{p}$ value $<0.05$, $\mathrm{T}$ statistic $>1.65$ and the positive path coefficient, it could mean that procedural justice has a positive

and significant effect on teacher performance. Based on the path coefficient value that connects the two variables, it can be seen that $56.9 \%$ of the variance in teacher performance is influenced by procedural fairness in schools.

Finally, the $\mathrm{p}$ value for the effect of work motivation on teacher performance (MOT KIN) is 0,000 with a $\mathrm{T}$ statistic of 4.074 and the path coefficient is positive at 0.531 . Because the $\mathrm{p}$ value $<0.05$, T statistic $>1.65$ and the positive path coefficient, it could be interpreted that work motivation has a positive and significant effect on teacher performance. Based on the path coefficient value that connects the two variables, it can be seen that $53.1 \%$ of the variance in teacher performance is influenced by teacher work motivation.

In PLS analysis, the simultaneous influence of all exogenous variables on endogenous variables can be seen from the $R$ square value for models with one exogenous variable and by looking at the adjusted $R$ Square value for models using more than one exogenous variable. The result is presented the following table.

Table 5. $R$ Square value

\begin{tabular}{ccc}
\hline & R Square & R Square Adjusted \\
\hline KIN & 0.508 & 0.486 \\
\hline
\end{tabular}

Based on the results of the analysis in the table above, the adjusted $R$ square value of the performance variable is 0.486 , this indicates that $48.6 \%$ of teacher performance is influenced by job satisfaction, procedural justice and work motivation, while the remaining $51.4 \%$ of teacher performance variance influenced by other factors beyond job satisfaction, procedural justice and work motivation.

The summary results of the research hypothesis testing is obtained as follows:

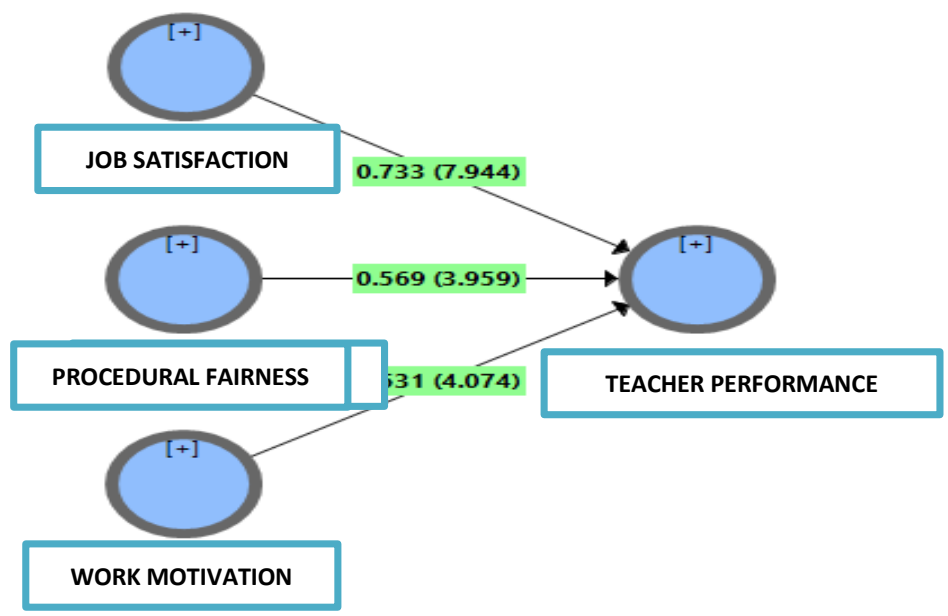

Figure 5 Hyphothesis Testing Result 


\section{CONCLUSION AND RECOMMENDATION}

\section{Conclusion}

Based on the findings and discussions, the research has met the research objectives with several conclusions formulated as follow:

1. Job satisfaction has a positive and significant effect on teacher performance, the higher the teacher's job satisfaction, the higher the teacher's performance, and vice versa. Also, 73.3\% of the variance in teacher performance is influenced by teacher job satisfaction.

2. Procedural fairness has a positive and significant effect on teacher performance, the better the school procedural fairness, the higher the teacher's performance, and vice versa. Then, $56.9 \%$ of the variance in teacher performance is influenced by procedural fairness in schools.

3. Work motivation has a positive and significant effect on teacher performance, the higher the work motivation of the teacher, the higher the teacher's performance, and vice versa. Moreover, $53.1 \%$ of the variance in teacher performance is influenced by teacher work motivation.

4. It is proved that $48.6 \%$ of teacher performance is influenced by job satisfaction, procedural justice and work motivation, while the remaining $51.4 \%$ of teacher performance variance is influenced by other factors beyond job satisfaction, procedural justice and work motivation.

\section{Recommendation}

Based on the conclusions above, several recommendations are put forward, namely:

1. Institutions and decision makers (superiors) are expected to be able to make decisions by considering matters that can increase the value of teacher job satisfaction so that teacher performance is maintained and even increases.

2. Decision makers (superiors) are expected to increase the value of procedural justice in the work environment of SMA Yuppentek 1 Kota Tangerang, so that teacher performance is maintained to meet the institution's goals

3. Institutions and decision makers are expected to make teachers see rewards and punishments clearly, make policies that increase teacher enthusiasm for work and teachers feel they have challenges to carry out their duties and responsibilities.

4. Institutions and decision makers (superiors) are expected to be closer to employees, especially teaching staff, so that employees can be open to superiors about problems that occur within the subordinates. Also, superiors should help solve problems or avoid situations where this can lead to feelings of dissatisfaction, injustice and have a negative impact on their work motivation and performance.

\section{BIBLIOGRAPHY}

Ahmadiansah, Reza. (2016). Pengaruh Motivasi Kerja dan Kepuasan Kerja terhadap Kinerja Guru SMK Muhammadiyah Salatiga. Unpublished Thesis. Salatiga: Sains Psikologi, Universitas Kristen Satya Wacana

Ananda Sabil Husein (2015). Penelitian Bisnis dan Manajemen Menggunakan Partial Least Squares (PLS) dengan smart PLS 3.0. Universitas Brawijaya: Modul Ajar

Ardiana, Titin E. (2017). "Pengaruh Motivasi Kerja Dan Kompetensi Profesional Terhadap Kinerja Guru Smp Negeri Di Kecamatan Jetis Kota Yogyakakarta”. Jurnal Akuntansi dan Pajak. Vol. 17, No. 2, hal

Arikunto, Suharsimi. (2010). Prosedur Penelitian Suatu Pendekatan Praktik. Jakarta: Rineka Cipta. 
Arikunto, Suharsimi. (2013). Prosedur Penelitian Suatu Pendekatan Praktik. Edisi Revisi. Jakarta: PT. Rineka Cipta

Azwar, Saifudin. (2012). Penyusunan Skala Psikologi edisi 2. Yogyakarta: Pustaka Pelajar

Depdiknas. 2003. Undang-undang RI No.20 tahun 2003.tentang sistem pendidikan nasional.

Ghozali, Imam. (2011). Aplikasi Analisis Multivariate Dengan Program SPSS. Semarang: Badan Penerbit Universitas Diponegoro.

Ghozali, Imam. (2014). Structural Equation Modeling, Metode Alternatif dengan Partial Least Square (PLS). Edisi 4. Semarang : Badan Penerbit Universitas Diponegoro

Habibullah, Habibullah. (2019). Pengaruh Keadilan Distributif, Keadilan Prosedural dan Keadilan Interaksional Terhadap Kinerja Karyawan pada PT. Citra Nusa Mutiara Padang. Unpubublished Diploma thesis, Universitas Andalas.

Irawan, L dan Sudarma, K. (2016). "Pengaruh Keadilan Distributif Dan Keadilan Prosedural Pada Komitmen Afektif Melalui Kepuasan Kerja”. Management Analysis Journal . Vol 5 No. 2)

Karina. (2013). Aplikasi SPSS. Serang: LPPM Sekolah Tinggi Bina Bangsa.

Kreitner, Robert, \& Kinicki, Angelo. (2001). Organizational Behavior. Fith Edition,. International Edition, Mc Graw-Hill companies. Inc.

Luthans, F.(2011). Organizational behavior (12th ed.). New York: McGraw-Hill, Inc.

Moekijat. (2010). Administrasi Kepegawaian Negara Indonesia. Bandung: CV Bandar Maju. (Cetakan ke 9)

Moorhead dan Grifin. (2013). Perilaku Organisasi Manajemen Sumber Daya Manusia dan Organisasi (Diana Angelica, Penerjemah.). Jakarta: Salemba Empat

Oslan, Abdul Wahid Syafar, dan Mauled Muelyono. (2015). "Pengaruh Disiplin Kerja , Gaya Kepemimpinan Dan Kepuasan Kerja Terhadap Kinerja Guru Di Sma Negeri 7 Palu." $e$ Jurnal Katalogis 3(4): 14-21.

Pamungkas, Widyanggoro dan Jabar, Cepi S Abdul. (2014). Pengaruh Profesionalitas, Kepuasan Kerja Dan Iklim Organisasi Terhadap Kinerja Guru SMKN Di Kabupaten Boyolali. Jurnal Akuntabilitas Manajemen Pendidikan Vol. 2 (2): 265-278

Rahmawati dan Tarsis. (2014). "Pengaruh Lingkungan Kerja dan Kompensasi Kerja Melalui Motivasi Kerja sebagai Variabel Intervening terhadap Kinerja Guru”. Jurnal Analisis Ekonomi, Universitas Negeri Semarang, Vol.3, No.2, hal. 311-318.

Rakhmawati Hajiyanti. (2013). Pengaruh Keadilan Prosedural Terhadap Komitmen Karyawan Dengan Tingkat Kepuasan Karyawan Sebagai Variabel Intervening. Unpublished diploma paper. Program Studi Akuntansi, Fakultas Ekonomi, Universitas Negeri Yogyakarta.

Riduwan, Akdon. (2011). Rumus dan Data dalam Aplikasi Statistika. Bandung : Alfabeta

Robbins, S P \& Judge, T A. (2013). Organizational Behavior. 15th Ed. New Jersey: Pearson Education

Sadiyo. (2014). "Uji Korelasi Motivasi dan Disiplin Kerja terhadap Kinerja Guru Dimoderasi Kepemimpinan Kepala Sekolah”. Jurnal Pendidikan, STMIK AKI Pati, Vol. I, No.1, hal. $39-48$.

Sari, Oxy R dan Susilo, H. (2018). "Pengaruh Kepuasan Kerja Terhadap Kinerja Karyawan Dengan Organizational Citizenship Behavior Sebagai Variabel Intervening (Studi Pada

Available Online: https://dinastirpub.org/DIJEMSS 
Karyawan Ptpn X - Unit Usaha Pabrik Gula Modjopanggoong Tulungagung)”. administrasibisnis.studentjournal.ub.ac.id, Vol. 64 (1), hal 28 - 35

Siagian, Sondang P. (2004). Teori motivasi dan Aplikasinya. Edisi 3. Jakarta: PT. Rineka Cipta. Sinambela, L P. (2016). Manajemen Sumber Daya Manusia : Membangun Tim Kerja Yang Solid Untuk Meningkatkan Kinerja. Jakarta : Bumi Aksara.

Siswanto, H. B. ( 2006). Pengantar Manjemen edisi kedua. Jakarta: PT. Bumi Aksara. Sondang Siagian. (2012). Teori Motivasi dan Aplikasinya. Jakarta: PT Rineka Cipta Subariyanti, H. (2017). "Hubungan Motivasi Kerja Dan Kepuasan Kerja Terhadap Kinerja Karyawan Ptlr Batan”. Ecodomica Vol 1 No. 2

Sulistiyani, Linda. (2015.) Pengaruh Kepuasan Kerja Dan Motivasi Kerja Terhadap Kinerja Guru Di SMK Negeri Se Kota Surakarta. Unpublished thesis, Universitas Muhammadiyah Surakarta

Sunyoto, Danang. (2015). Teori Perilaku Keorganisasian. PT Buku Seru, Yogyakarta. Supardi. (2014). Kinerja Guru. Jakarta: PT. Raja Grafindo Persada

Sutrisno, Edy. (2012). Manajemen Sumber Daya Manusia. Edisi 1. Cetakan Keempat. Prenada Media Group. Jakarta.

Wahyudi, B. (2012). Manajemen Sumber Daya Manusia. Bandung: Sulita

Wibowo. (2011). Manajemen Kinerja. Jakarta: Raja Grafindo Persada

Widiastuti, Rosita Kharisma. (2016). "Pengaruh Keadilan Prosedural Terhadap Kinerja Karyawan Dengan Tingkat Kepuasan Karyawan Sebagai Variabel Intervening”. Jurnal Nominal. Vol. V, No. 1, hal 88 - 96

Yulk, Gary. (2010). Kepemimpinan dalam Organisasi. Ed kelima. Jakarta: Indeks. 